J. Perinat. Med. $16(1988) 109$

\section{Simultaneous recording of fetal breathing movements and body move- ments in twin pregnancy}

\author{
Etan Z. Zimmer, Israel Goldstein, and Sarit Alglay \\ Department of Obstetrics and Gynecology "B", Rambam Medical Center, \\ Technion Faculty of Medicine, Haifa, Israel
}

\section{Introduction}

Antenatal evaluation of fetal wellbeing is of special importance in twin pregnancies as perinatal mortality and morbidity is increased in these cases. Fetal body movements and breathing movements are regarded as important indicators of fetal health and are part of the fetal biophysical scoring system.

Biophysical scoring was reported in twin pregnancies $[6,11]$ but unfortunately there are only very few reports on the pattern of activity as well as on the synchroneous mode of different types of fetal activities in twin fetuses $[9,12]$.

The aim of the present study was to determine if fetal body movements and breathing movements in twin pregnancy are influenced by the position, presentation or sex of the fetuses. By simultaneous recording of both fetuses we tried to find out if there is a synchrony between the different types of movements in twin fetuses.

\section{Material and methods}

Thirty healthy parturients with a twin gestation at 34 to 37 weeks were enrolled in the study after giving an informed consent. All fetuses were normal. The position, presentation and sex of each fetus was defined by ultrasound. Afterwards simultaneous recording of fetal breathing movements and trunk movements of both fetuses was performed with two real time scanners. All recordings were performed in the afternoon at least two hours after the last meal. The recording period was exactly $40 \mathrm{~min}$. The number and duration in seconds of breathing periods and fetal trunk movements were coded with event markers. Apnea was defined as the absence of breathing movements for six or more seconds. Total fetal activity was defined as the amount of time the fetus had either breathed or moved.

Recordings were made by expert observers whose position (on the right or left side of the patient) were randomized. Patients lay on the back or with a tilt to the left semirecumbent position.

\section{Results}

All infants were normal and healthy at delivery.

Sex: There were 31 males and 29 females. In 8 pairs both fetuses were males, and in 7 pairs both were females.

Position: In 23 pairs both fetuses were in a longitudinal lie. In one pair both fetuses were in transverse lie while in another 6 gestations one of the fetuses was in transverse lie.

Presentation: 31 fetuses were in cephalic presentation and 21 fetuses in breech presentation. In 9 pairs both fetuses were in cephalic presentation while breech presentation of both fetuses was found in 5 pairs.

\subsection{Fetal activity: Right versus left position}

The activity of fetuses positioned on the right side of the uterus was compared to those on the left side. All values will be given as mean $\pm S$. $D$.

In 23 pairs where both fetuses were in longitudinal position the duration of breathing movements was 
longer on the right side $1299 \pm 1082$ vs $761 \pm 810$ $\sec (p=0.002)$. Total activity was also longer on the right side $1699 \pm 995$ vs $1082 \pm 829 \mathrm{sec}$ $(\mathrm{p}<0.0001)$.

Six pairs both fetuses were males. The fetus on the right side was found to be more active. The number of breathing periods was $33 \pm 15$ vs $17 \pm 12(\mathrm{p}=0.045)$. Duration of breathing movements $1837 \pm 1050$ vs $857 \pm 901 \mathrm{sec}$ (p < 0.02). The total activity $2092 \pm 1057$ vs 1179 $\pm 845 \mathrm{sec}(\mathrm{p}=0.043)$.

In the five pairs of female fetuses, there was a trend of more activity of the right fetus. Taking into consideration all eleven pairs where both fetuses were of the same sex it was found again that the fetuses on the right side were more active. Breathing movements $1486 \pm 883$ vs $778 \pm 685$ $\sec (\mathrm{p}=0.008)$. Total activity $1833 \pm 820$ vs 1040 $\pm 686 \sec (\mathrm{p}=0.004)$.

In 9 gestations both fetuses were in cephalic presentation. The fetuses on the right side were found to have longer breathing movements, $1357 \pm 756$ vs $645 \pm 507 \sec (\mathrm{p}=0.026)$ as well as longer total activity. $1663 \pm 623$ vs $856 \pm 518 \mathrm{sec}$ $(\mathrm{p}=0.012)$.

There were 14 pairs in the same presentation (both cephalic or both in breech). The duration of breathing movements and total activity of the right sided fetuses were significantly longer. Breathing movements $1491 \pm 1110$ vs $902 \pm 785$ sec $(\mathrm{p}=0.011)$. Total activity $1848 \pm 1020$ vs $1151 \pm 1020$ vs $1151 \pm 856 \sec (\mathrm{p}=0.002)$.

In 9 gestations both fetuses were of the same sex and in the same presentation. The fetuses on the right side performed longer breathing movements $1076 \pm 821$ vs $846 \pm 728 \mathrm{sec}(\mathrm{p}=0.005)$. The total activity was also longer on the right side $2027 \pm 779$ vs $1058 \pm 764 \sec (p=0.002)$.

\subsection{Simultaneous fetal activities}

In 26 pairs of twins simultaneous recording of fetal activities was performed. On the same 4 channels recorder, enabling an accurate evaluation of the time fetuses spend in simultaneous activity. The total time of activity of these fetuses was $78025 \mathrm{sec}$. Simultaneous activity was found during $41626 \sec (53.3 \%)$.

States at which one fetus breathed while his twin fetus moved occurred during $7944 \mathrm{sec}$ which are $10.2 \%$ of the total activity periods.
Fetal body movements: The duration of movements in all pairs was 19807 sec. Simultaneous movements were seen during $5146 \mathrm{sec}$ which is $26 \%$ of the time. In two pairs no simultaneous movements were found. The effect of fetal sex and fetal presentation on simultaneous movements was evaluated. The distribution of time of simultaneous movements was not significantly influenced by the fact that fetuses were of the same sex or of different sex. The fact that fetuses were in the same presentation or in different presentations also had no significant influence. Of importance is to note that all fetuses performed body movements during the study period.

Fetal breathing movements: Three fetuses did not breathe during the study. In another two gestations no simultanous fetal breathing was found. The duration of breathing periods wass $58218 \mathrm{sec}$. Simultaneous breathing movements were seen during $14268 \mathrm{sec}$ which are $49 \%$ of the time. The distribution rate of simultaneous breathing was not significantly affected by the sex or presentation of the fetuses. We could only find a trend of more simultaneous activity in pairs which were in different presentation.

\section{Discussion}

Twin fetuses differ in many aspects from each other in the antenatal period. At present there is only little data on the factors that might affect the pattern of intrauterine activity of these fetuses. It is also not known to what extent fetal breathing and body movements are synchroneous in twin fetuses.

In our study twins were simultaneously evaluated for $40 \mathrm{~min}$. Although Patrick and Challis [10] recommended an evaluation of at least $90 \mathrm{~min}$ to encompass a complete cycle of breathing movements most investigators used a period of $30 \mathrm{~min}$ in their studies on fetal activity. The recommended period for evaluation of the biophysical profile is also $30 \mathrm{~min}[6,8,11]$. The usual length of the nonstress test is $20 \mathrm{~min}$ which are extended to 40 $\mathrm{min}$ if fetal reactivity is not recorded.

Recording of breathing and body movements was directly performed. The position of the observers on the right or left side of patient was randomized and they were not blinded to the "sideness" of the fetuses. It is important to note that even if taped observations were used observers could not be blinded to the sex and presentation of the fetus. 
MARSAL et al. [9] found a significant internal difference in the distribution of apnea and periodic breathing between twin I and twin II fetuses if both were in cephalic presentation. This was more pronounced if twin I was female. On the other hand, no such difference was found with twin I in breech presentation. Unfortunately the recordings of fetal activities in this study were not performed simultaneously but in two consecutive periods and changes in maternal and environmental factors could not be excluded. No difference between breech presentation and other presentations was found in our patients.

In a recent study [12] it was suggested that in twin pregnancy fetal movements which occur in one fetus independent of the other one, are spontaneous movements while movements which occur simultaneously in both fetuses are evoked by environmental stimuli. The rate of simultaneous movements was $24.3 \%$ which is very similar to our results which was $26 \%$. Our study was more extended, and we found that simultaneous breathing occured during $49 \%$ of the breathing periods. The fact that simultaneous breathing movements are longer than body movements can be explained in part by the fact that the duration of breathing is much longer than the duration of body movements. Undoubtedly other maternal and environmental factors might have an influence too.

Our most consistent finding was that the fetus positioned on the right side of the uterus was more active. This was mainly due to more breathing activity. We could find no other report in the

\section{Summary}

Fetal breathing and body movements were simultaneously evaluated in twin pregnancies in order to determine to what extent these activities occur in a synchroneous pattern in both twin fetuses and if fetal position, presentation or sex have an influence on their behavior. Thirty healthy pairs of twins at $34-37$ weeks of gestation were studied. Twenty-six percent of fetal body movements and $49 \%$ of breathing movements occurred simultaneously in both fetuses. The overall total simultaneous fetal activity rate was $53.3 \%$.

Keywords: Fetal body movements, fetal breathing movements, twins.

\section{Zusammenfassung}

Simultane Aufzeichnung von Atem- und Körperbewegungen bei Zwillingsschwangerschaften

Wir erfaßten simultan die fetalen Atem- und Körperbe- literature on the difference between right and left positioned twins. In previous studies differences in fetal heart rate reactivity were noted in NST recordings of twins in cases where one of the fetuses was growth retarded or in distress $[1,2,4$, 7]. A high synchrony rate of twin NST responses was found when placental sites were common or shared and lower when placentation was separate [4]. All sixty fetuses recorded by us were healthy, normal and with a birth weight in the normal limits. No significant difference in sex or presentation was found between the right and left positioned fetuses. Due to technical problems an accurate examination of placentas was not performed, but great differences between them are most unlikely as our study population was normal. At present we can only speculate on the reason why right positoned fetuses are more active. Theoretically a difference in blood flow could be suggested. Unfortunately recent studies on blood flow in the uterine arteries during normal pregnancy do not refer to the possibility of different flow in the left and right side [3,13]. In a study on the fetal umbilical artery flow velocity-time waveforms in twin pregnancies [5] the ratio of peak systolic to least diastolic velocity was in the normal range in all pairs of twins who had an appropriate birth weight. Differences were noted in growth retarded fetuses and in cases of twin to twin transfusion.

In conclusion, fetuses positioned on the right side of the uterus are more active than twin fetuses on the left side. The reason for this phenomenon is still obscure.

The length of breathing movements and total activity (summation of breathing and body movements) of the fetuses positioned on the right side of the uterus were significantly longer than in fetuses positioned on the left side of the uterus $(p=0.002)$ and $(p<0.0001)$ respectively. This was also true for subgroups where only fetuses in the same presentation or of the same sex were compared. It is concluded that the fetus positioned on the right side of the uterus is more active and that fetal sex or presentation had no significant effect on intrauterine fetal activity in twin pregnancies. wegungen bei Zwillingsschwangerschaften, um herauszufinden, in welchem Ausmaß diese Aktivitäten synchron bei den Gemini erfolgen und ob die Lage oder 
das Geschlecht einen Einfluß auf das Verhalten haben. Untersucht wurden 30 gesunde Zwillingspärchen zwischen der 34. und 37. Schwangerschaftswoche. $26 \%$ der fetalen Körperbewegungen und $49 \%$ der Atembewegungen erfolgten synchron bei beiden Feten. Insgesamt betrug die Rate der simultanen fetalen Aktivitäten 53.3\%. Atembewegungen sowie auch die Summe aus Atem- und Körperbewegungen waren bei Feten in der II. Lage länger bzw. größer als bei Feten in der I. Lage $(p=0.002$ bzw. $\mathrm{p}<0.0001$ ). Das galt ebenso für Untergruppen, d. h., wenn nur Feten mit gleichem vorangehendem Teil oder Feten mit dem gleichen Geschlecht einander gegenübergestellt wurden. Wir schließen daraus, daß der Fet in der II. Lage aktiver ist und daß das Geschlecht oder der vorangehende Teil keinen signifikanten Einfluß auf die intrauterine fetale Aktivität bei Zwillingsschwangerschaften hat.

Schlüsselwörter: Fetale Atembewegungen, fetale Körperbewegungen, Zwillinge.

\section{Résumé}

Enregistrement simultané des mouvements respiratoires et des mouvements corporels des fetus au cours de la grossesse gemellaire

On a évalué de façon simultanée les mouvements fotaux respiratoires et corporels chez les grossesses gemellaires afin de trouver jusqu'à quel point ces activités surviennent de façon synchronisée chez les deux jumeaux et si la position fotale, la présentation ou le sexe exercent une influence sur leurs comportements. 30 paires de jumeaux en bonne santé à $34-37$ semaines de gestation ont été étudiées. $26 \%$ des mouvements corporels et $49 \%$ des mouvements respiratoires fotaux surviennent simultanément chez les 2 fœtus.
L'activité fotale simultanée globalement représente $53,3 \%$. Les mouvements respiratoires et l'activité totale (somme des mouvements respiratoires et corporels) des fœtus situés dans la partie droite de l'utérus sont plus longs de façon significative que pour les fœtus situés dans la partie gauche (respectivement $p=0,002$ et $\mathrm{p}<0,0001$ ). Celà est vrai également pour les sous-groupes dans lesquels les fœetus ont la même présentation ou sont de même sexe. On en conclue que les fotus placés dans la partie droite de l'utérus sont plus actifs et que ni le sexe ni la présentation n'ont d'influence significative sur l'activité fotale intra-utérine au cours des grossesses gemellaires.

Mots-clés: Mouvements corporels du fœtus, movements respiratoires fætaux, jumeaux.

Acknowledgements: We would like to thank Mrs. ADA TAMIR for her help in the statistical analysis.

\section{References}

[1] Bailey, D, AM FlynN, J Kelly, M O’Conor: Antepartum fetal heart rate monitoring in multiple pregnancy. Br J Obstet Gynecol 87 (1980) 581

[2] Blake GD, RA Knuppel, CJ Ingarida, M Lake, G Aumann, M Hanson: Evaluation of nonstress fetal heart rate testing in multiple gestations. Obstet Gynecol 63 (1984) 528

[3] Campbell S, J Diaz-Recasens, DR Griffin, TE Cohen-Overbeek, JM Pearce, K Willson, MJ TEAGUE: New doppler technique for assessing uteroplacental blood flow. Lancet 1 (1983) 675

[4] Devoe LD, H Azor: Simultaneous nonstress fetal heart rate testing in twin pregnancy. Obstet Gynecol 58 (1981) 450

[5] Giles WB, BJ Trudinger, CM CoOK: Fetal umbilical artery flow velocity time waveforms in twin pregnancies. Br J Obstet Gynecol 92 (1985) 490

[6] LANGE IR, FA MANNING: Fetal biophysical assessment: An ultrasound approach. Semin Ultrasound CT MR 5 (1984) 269

[7] LeNSTRUP C: Predictive value of antepartum nonstress test in multiple pregnancies. Acta Obstet Gynecol Scand 63 (1984) 597

[8] Manning FA, IR Lange, I Morrison, CR HarMAN: Fetal biophysical score and the nonstress test: A comparative trial. Obstet Gynecol 64 (1984) 326
[9] Marsal K, G GenNSer, S Kullander: Intrauterine breathing movements and fetal presentation. Obstet Gynecol 51 (1978) 163

[10] Patrick J, J Challis: Measurements of human fetal breathing movements in healthy pregnancies using a real time sanner. Semin Perinatol 4 (1980) 275

[11] Platt LD, GS Eglinton, L Sipos, PM Broussard, RH PAUL: Further experience with the fetal biophysical profile. Obstet Gynecol 61 (1983) 480

[12] Sadovsky E, G OHel, A Simon: The incidence of spontaneous and evoked fetal movements in twin pregnancy. 12 Annual Meeting of the Society for the Study of Fetal Physiology. Haifa, Israel 1985

[13] TAYLOR KJW, PN BurNS, PNT Wells, DI CONWAY, MGR HuLL: Ultrasound doppler flow studies of the ovarian and uterine arteries. Br J Obstet Gynecol 92 (1985) 240

Received May 19, 1987. Accepted October 9, 1987.

E. Z. Zimmer, M. D.

Department of Obstetrics and Gynecology

Rambam Medical Center

Haifa, Israel 